\title{
Galium suecicum (Rubiaceae), a new and relict species in the flora of Poland
}

\author{
Jerzy Kruk ${ }^{1, *}$, Aleksandra Grabowska-Joachimiak ${ }^{2}$ \& Renata Szymańska ${ }^{3}$
}

1) Department of Plant Physiology and Biochemistry, Faculty of Biochemistry, Biophysics and Biotechnology, Jagiellonian University, Gronostajowa 7, PL-30-387 Kraków, Poland ( ${ }^{*}$ corresponding author's e-mail: jerzy.kruk@uj.edu.pl)

2) Department of Plant Breeding and Seed Science, University of Agriculture in Kraków, Łobzowska 24, PL-31-140 Kraków, Poland

3) Department of Medical Physics and Biophysics, Faculty of Physics and Applied Computer Sciences, AGH University of Science and Technology, Reymonta 19, PL-30-059 Kraków, Poland

Received 22 Jan. 2014, final version received 12 Mar. 2014, accepted 13 Mar. 2014

Kruk, J., Grabowska-Joachimiak, A. \& Szymańska, R. 2014: Galium suecicum (Rubiaceae), a new and relict species in the flora of Poland. - Ann. Bot. Fennici 51: 273-278.

In order to verify a possible occurrence of Galium suecicum (Rubiaceae) at the locations reported by P. Decker in 1911 under G. pumilum (G. silvestre) in the territory of western Poland, we visited all the identified stands during the years 2012 and 2013. At two of those sites, we found plants belonging to G. pumilum agg. that after thorough morphological and cytological studies turned out to be G. suecicum. These are presently the only known stands of this relict species in central Europe.

\section{Introduction}

The Galium pumilum complex in Europe includes a number of species with a broad ecological spectrum, from bare rocks to open forests, and with very different distributions, from very broad, e.g. G. pumilum s. stricto, to narrow endemic species, such as G. cracoviense (Ehrendorfer 1962, Meusel \& Jäger 1992, Kolář et al. 2013). In central Europe, the complex is represented by $G$. anisophyllon (diploid and tetraploid), G. cracoviense (diploid), G. pumilum s. stricto (octaploid), G. sudeticum (tetraploid) and G. valdepilosum (diploid and tetraploid) (Kolár et al. 2013).

One of the most intriguing species of the group is G. suecicum that was originally treated as $G$. pumilum subsp. suecicum and then raised to the species level (Ehrendorfer 1960). Galium suecicum is a postglacial relict with a disjunctive distribution. It is known from Västergötland, SE Sweden (provinces of Skåne, Blekinge, Småland) and from extinct stands in north Germany (Brandenburg province; Meusel \& Jäger 1992, Kolář et al. 2013). This species has been never reported from the territory of Poland, however it was marked to occur in the Wielkopolska region in the species distribution maps by Ehrendorfer (1962) and Meusel and Jäger (1992). Those localities were neither discussed in the literature nor supported by herbarium material. On the other hand, G. pumilum (G. silvestre) was reported by Decker (1911) east and southeast of Frankfurt am Oder, i.e. close to the Brandenburg region and that raised the possibility that $G$. suecicum could still occur at those localities.

In order to verify the possible occurrence of G. suecicum at the locations given by Decker 


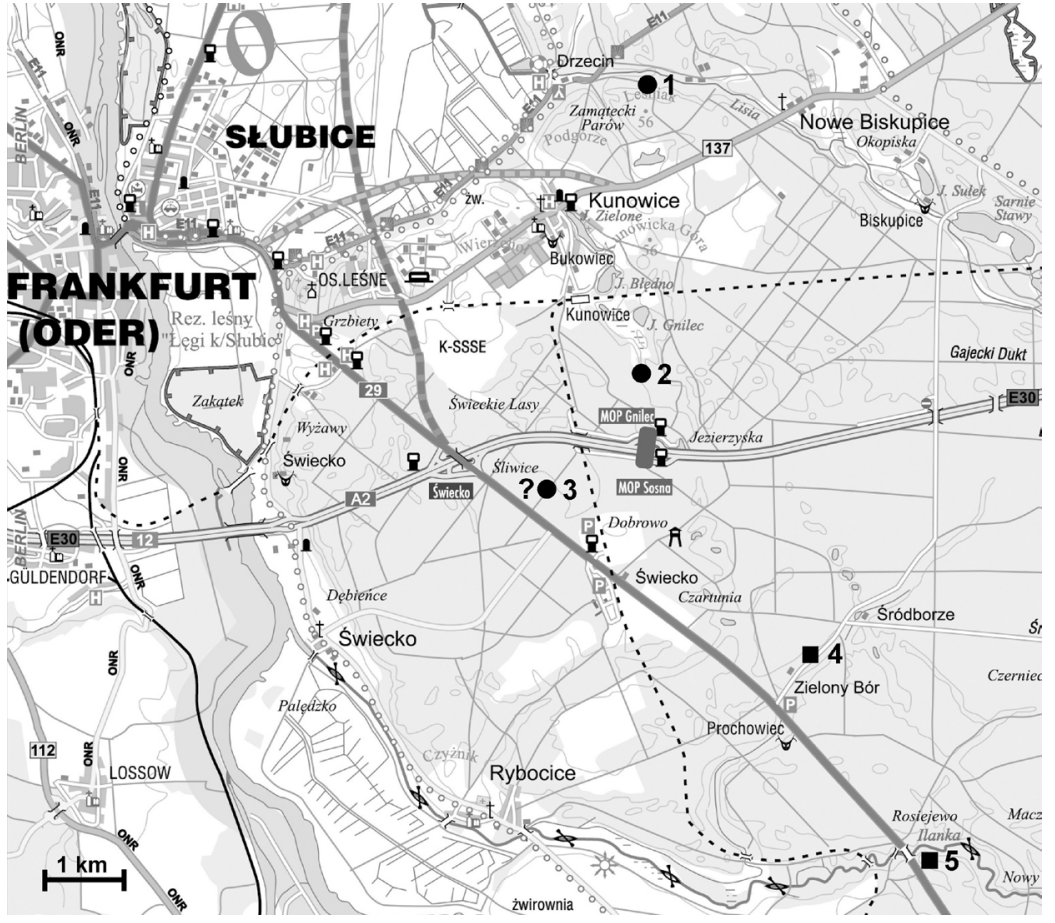

Fig. 1. Sites of Galium pumilum (G. silvestre) in the vicinity of Frankfurt/ Oder-Słubice reported by Decker (1911) and verified for the presence of G. suecicum in the current studies. = localities not confirmed, $\mathbf{\square}=$ confirmed stands and identified as G. suecicum, ? = location uncertain.
(1911) under G. pumilum (G. silvestre), we visited all the identified localities during the years 2012 and 2013. At two of the sites, we found plants belonging to G. pumilum agg. that after thorough morphological and cytological studies turned out to be G. suecicum. These are presently the only known sites of this species in central Europe.

\section{Material and methods}

Field studies were performed in 2012 and 2013 in the regions of western Poland where G. pumilum (G. silvestre) was reported to occur by Decker (1911). Identification of the localities described by Decker was performed using maps from Map Archives of Western Poland (http:// mapy.amzp.pl/maps.shtml). An ATPOL map was created using Gnomon 3.3 software. Geographical coordinates were determined with a Garmin Legend HCx GPS receiver. The species nomenclature follows Mirek et al. (2002).

For cytological studies, the plant material collected in the field was grown for several weeks in a phytotron chamber to stimulate for- mation of new roots. The root fragments with growth tips were incubated in saturated water solution of $\alpha$-bromonaphtalene for ca. 24 hours at $4{ }^{\circ} \mathrm{C}$. Next, the root fragments were fixed in absolute ethanol/glacial acetic acid (3:1, vol/vol). Fixed root tips were rinsed with distilled water, hydrolyzed in $1 \mathrm{~N} \mathrm{HCl}$ at $60{ }^{\circ} \mathrm{C}$ for $10 \mathrm{~min}$ and squashed in $45 \%$ acetic acid. After freezing in liquid nitrogen, the cover glasses were removed and the squashes were stained with $0.1 \%$ aqueous solution of toluidine blue. Chromosome observations were performed using a Nikon Microphot-FXA microscope. The images were captured and processed with a Nikon DSFilc camera and the NIS Elements software.

\section{Results}

Revision of the localities described by Decker (1911) revealed the presence of $G$. pumilum agg. only at sites 4 and 5 (Fig. 1) in the southern part of the investigated area. Those sites correspond to $\mathrm{AD} 03$ and $\mathrm{AD} 13$ squares, respectively in the ATPOL grid $(10 \times 10 \mathrm{~km}$ squares $)$ (Fig. 2). Although the sites are situated in differ- 
ent ATPOL squares, they are close to each other, ca. $3 \mathrm{~km}$ apart.

The investigated species is loosely caespitose (Fig. 3), with fragile, thin stems 5-15(20) $\mathrm{cm}$ long and with elongated middle internodes (Fig. 4). The leaves are $0.5-1 \mathrm{~cm}$ long, in whorls of 5-6, and usually strongly hairy (Fig. 5). The stems are most frequently also hairy, mainly in the middle and upper parts (Fig. 5). The flowers are densely arranged on very short pedicels (Fig. 5). The fruits are distinctly acutely papillose (Fig. 6), very similar to those of G. cracoviense and clearly different from those of $G$. pumilum s. stricto (Kucowa 1962, Ehrendorfer 1976). The species is diploid $(2 \mathrm{n}=22$; Fig. 7). All these data indicate unequivocally that the species is G. suecicum.

Among the two stands of G. suecicum found, the one located near Zielony Bór (Green Forest) (stand 4 in Fig. 1) was very small and covered about $1 \mathrm{~m}^{2}$ at the edge of a pine forest $\left(52^{\circ} 18^{\prime} 4.5^{\prime \prime} \mathrm{N}, 14^{\circ} 40^{\prime} 49.3^{\prime \prime} \mathrm{E}\right)$, while the second (stand 5 in Fig. 1) was considerably larger and the area covered (N limit 52 $16^{\prime} 47.5^{\prime \prime}, \mathrm{S}$ limit $52^{\circ} 16^{\prime} 44.9^{\prime \prime}, \mathrm{W}$ limit $14^{\circ} 42^{\prime} 2.2^{\prime \prime}$, E limit $\left.14^{\circ} 42^{\prime} 21.6^{\prime \prime}\right)$ was estimated to be $0.13-0.14$ $\mathrm{km}^{2}$ (Fig. 8) situated at 40-50 $\mathrm{m}$ a.s.l. In the most western part of the area, G. suecicum was found in an open mixed forest dominated by

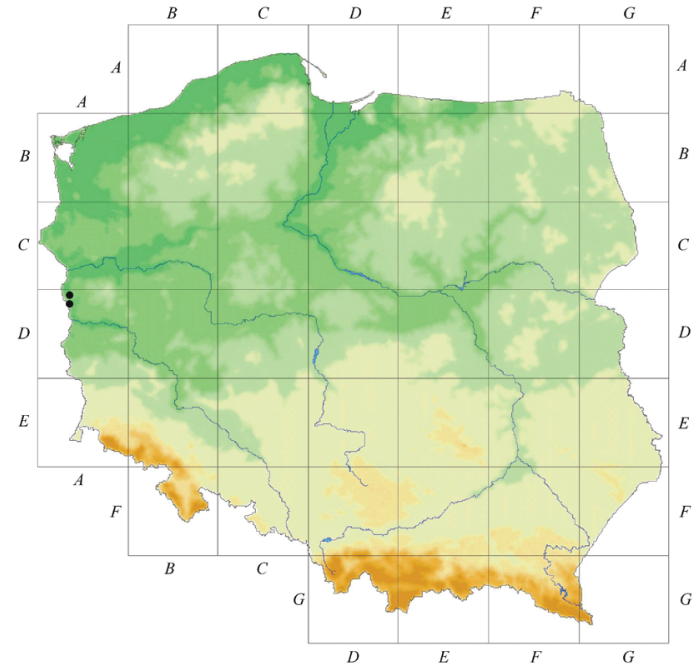

Fig. 2. Distribution of Galium suecicum in Poland in the ATPOL grid.

Quercus robur (continental mixed forest; Fig. 9), while in the other area, the species grew in open pine forest (ca. 30 years old) with Fagus silvatica and sporadically seedlings of Acer platanoides, Quercus robur and Sorbus aucuparia (Fig. 10). Among herbaceous species, G. suecicum was associated with Achillea millefolium, Anthoxanthum odoratum, Calamagrostis arundinacea, Euphorbia cyparissias, Festuca duvalli,
Fig. 3. Galium suecicum (site 5 in Fig. 1; photo by J. Kruk, 3 May 2012).

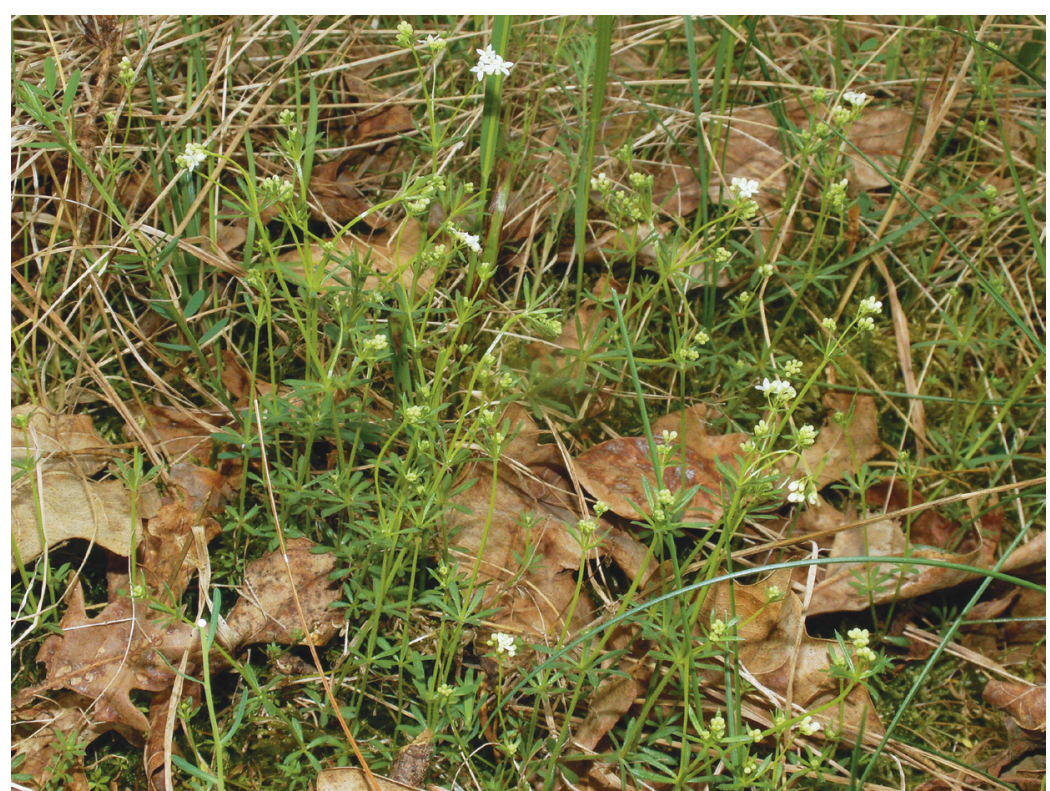




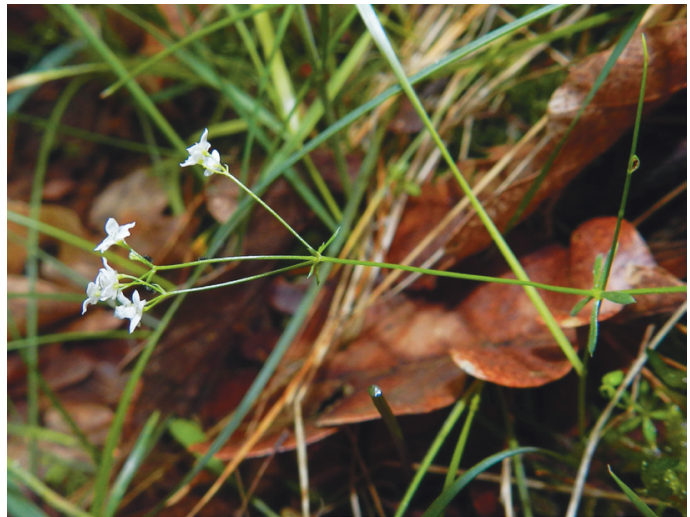

Fig. 4. Galium suecicum in bloom (site 5 in Fig. 1; photo by J. Kruk, 1 June 2013).

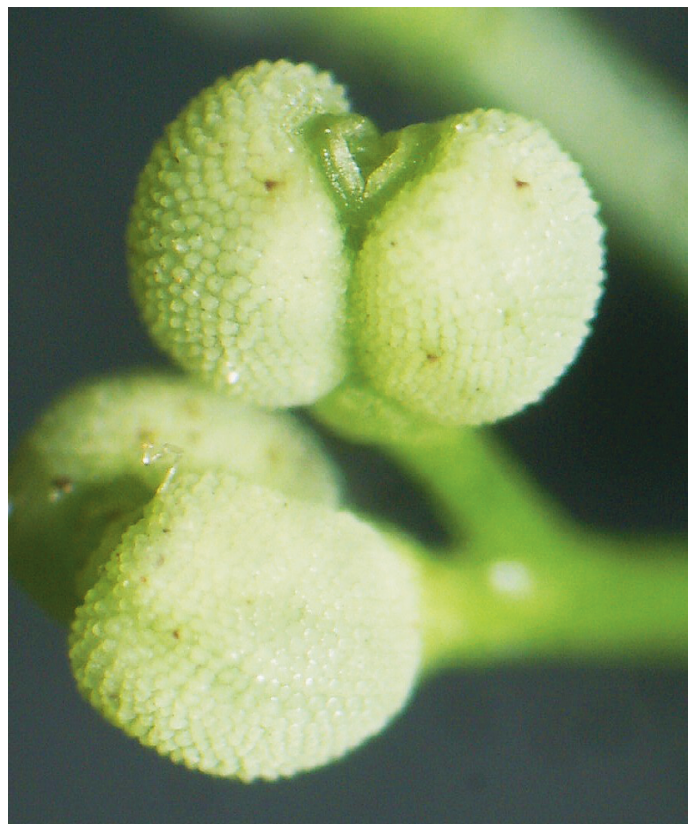

Fig. 6. Fruits of Galium suecicum (site 5 in Fig. 1).

Festuna ovina s. stricto, Fragaria vesca, Galium verum, Hypericum perforatum, Melica nutans, Peucedanum oreoselinum, Pimpinella nigra, Pleurozium schreberi (moss), Poa pratensis, Rumex acetosella, Vaccinium myrtillus, Veronica officinalis, V. teucrium, Vicia hirsuta, and Viola tricolor. In this area G. suecicum was found usually in patches covering up to $1-4 \mathrm{~m}^{2}$. Its blooming period was estimated to be at end of May and beginning of June.

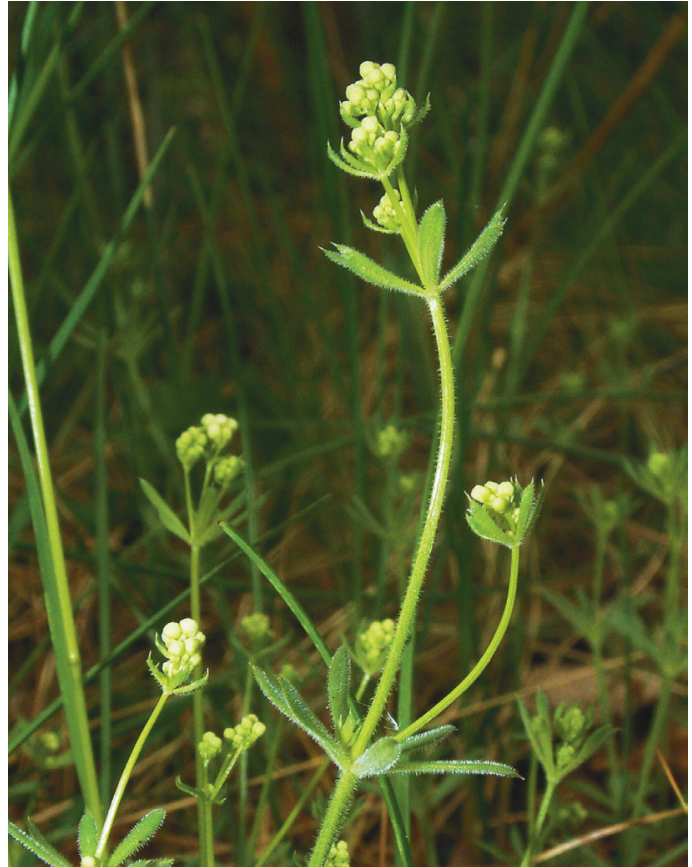

Fig. 5. Galium suecicum close-up before blooming (site 5 in Fig. 1; photo by J. Kruk, 3 May 2012).

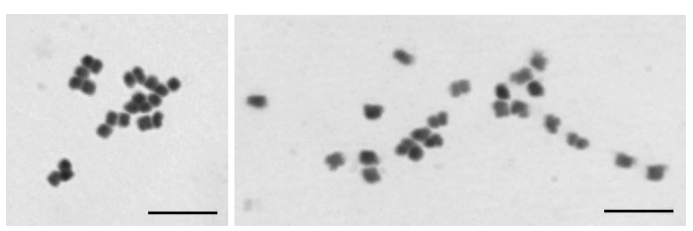

Fig. 7. Metaphase plates $(2 \mathrm{n}=22)$ of Galium suecicum collected from site 5 in Fig. 1. Bar $=5 \mu \mathrm{m}$.

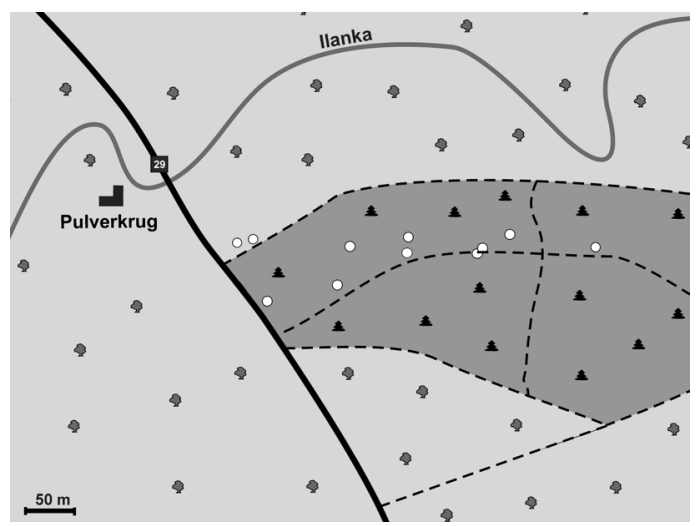

Fig. 8. Detailed distribution map of Galium suecicum near the remnants of Pulverkrug (Rosiejewo) (site 5 in Fig. 1). The white dots indicate abundant occurrences. 
Fig. 9. Habitat of Galium suecicum at the western border of site 5 in Fig. 1 (photo by J. Kruk, 1 June 2013).

Fig. 10. Typical habitat of Galium suecicum (site 5 in Fig. 1; photo by J. Kruk, 1 June 2013).
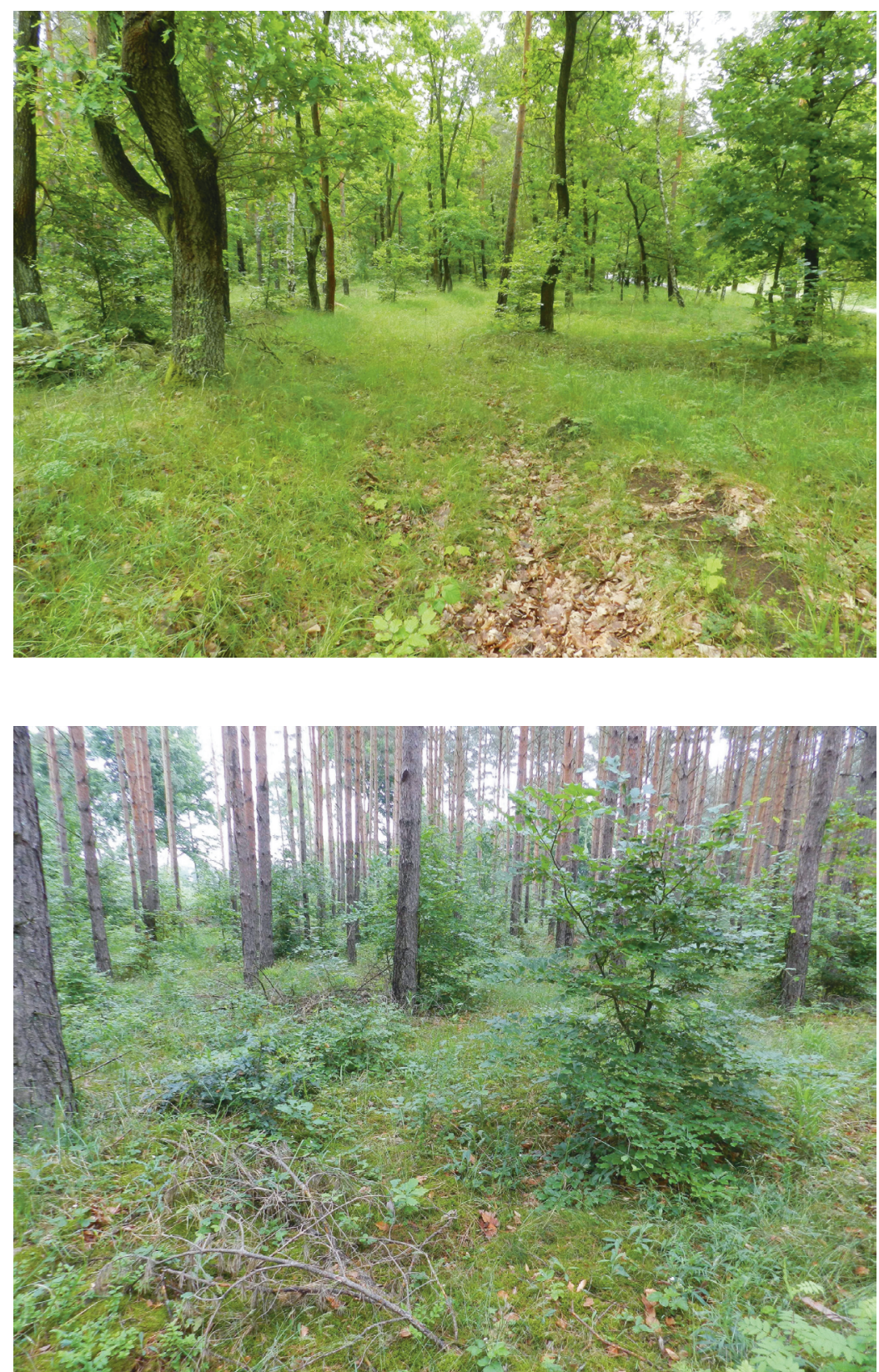

The G. pumilum sites reported by Decker (1911) are as follows (numbers as in Fig. 1): (1) Kunersdorf (Kunowice): zwischen Bäcker- und Rätschmühle, (2) bei Pauls Born (name of spring area), (3) am Wege im Walde von der Chaussee nach der Försterei, (4) Grüner Tisch (Zielony Bór), (5) Pulverkrug (Rosiejewo; a village no longer there).

\section{Discussion}

The present discovery of G. suecicum is valuable taking into consideration the fact that this species has probably been extinct since long time ago in northern Germany (Kolár et al. 2013), at the southern limit of its general distribution. At the currently found sites, it grows in similar 
habitats as described in the literature, i.e. in open pine forests (Ehrendorfer 1962, Kolár et al. 2013). Although the identified area covered by G. suecicum is very small, it is highly probable that it grows also at other sites in the spacious forest area east and south-east of Frankfurt/ Słubice.

The relict stand of G. suecicum is interesting in light of the origin of endemic species in deglaciated areas of central and northern Europe (Kolář et al. 2013), as well as of the evolution of species in the whole G. pumilum complex in Europe. Regardless of which of the several theories (Kolár et al. 2013) of the origin of the present distribution of species in the G. pumilum complex in northern and central Europe is valid, it cannot be questioned that the presently existing diploid species of the complex (e.g. $G$. cracoviense, $G$. oleandicum, G. sternieri) originate from a diploid species, while polyploid species evolved later. If the G. pumilum complex is monophyletic, the ancestor of the whole complex was certainly diploid with a more or less wide distribution, most probably in western and/or central Europe, from where it spread to the present area. Among the diploid species that could have given rise to other species in the complex might be a direct ancestor of G. suecicum or G. valdepilosum. Although G. suecicum is currently mainly distributed in Sweden, its original distribution was probably in western and/or central Europe and after climate change, during a deglaciated period, the species moved to colder areas in Sweden and northern Germany-Poland and became extinct at its original area of distribution. Thus, the present sites of $G$. suecicum in western Poland may be relicts of its original distribution range.

\section{Acknowledgements}

We are grateful to SYGNATURA (www.sygnatura.com.pl) for letting us use a fragment of the map 'Pojezierze lubuskie 1:100 000' (ISBN 978-83-7499-040-0). We thank dr Marcin Nobis for the determination of Festuca duvalli.

\section{References}

Decker P. 1911: Beiträge zur Flora der südlichen Neumark und der östlichen Niederlausitz. - Verhandlungen des Botanischen Vereins der Provinz Branderburg 53: 87-269.

Ehrendorfer F. 1960: Neufassung der Sektion Lepto-Galium Lange und Beschreibung neuer Arten und Kombinationen. - Sitzungsberichten der Österreichischen Akademie der Wissenschaften, Mathematisch-Naturwissenschaftliche Klasse, Abt. I, 169: 407-421.

Ehrendorfer F. 1962: Cytotaxonomische Beiträge zur Genese der mitteleuropäischen Flora und Vegetation. - Berichte der Deutschen Botanischen Gesellschaft 75: 137-152.

Ehrendorfer F. 1976: Galium L. - In: Tutin T.G., Heywood V.H., Burges N.A., Moore D.M., Valentine D.H., Walters S.M. \& Webb D.A. (eds.), Flora Europaea, vol. IV: 14-36. University Press, Cambridge.

Kolář F., Lučanová M., Vít P., Urfus T., Chrtek J., Fér T., Ehrendorfer F. \& Suda J. 2013: Diversity and endemism in deglaciated areas: ploidy, relative genome size and niche differentiation in the Galium pusillum complex (Rubiaceae) in northern and central Europe. - Annals of Botany 111: 1095-1108.

Kucowa I. 1962: Gatunki rodzaju Galium L. Sekcji Leptogalium Lange z Polski i ziem ościennych [Species of the genus Galium L. of the section Leptogalium Lange in Poland and neighbouring territories]. - Fragmenta Floristica et Geobotanica 7: 417-442. [In Polish with English summary]

Meusel H. \& Jäger E. 1992: Vergleichende Chorologie der Zentraleuropeischen Flora, Bd. III. - Gustav Fischer Verlag, Jena-Stuttgart-New York.

Mirek Z., Piękoś-Mirkowa H., Zając A. \& Zając M. 2002: Flowering plants and pteridophytes of Poland $-a$ checklist. - W. Szafer Institute of Botany, Polish Academy of Science, Kraków. 